\title{
The Rise and Fall of Culture History
}




\section{The Rise and Fall of Culture History}

\section{R. Lee Lyman}

Michael J. O'Brien

University of Missouri-Columbia

Columbia, Missouri

\section{and}

\section{Robert C. Dunnell}

University of Washington

Seattle, Washington 


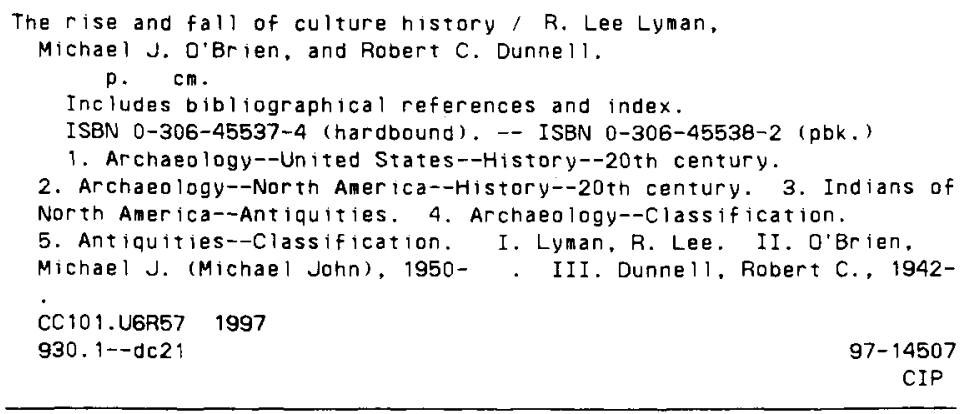

Cover illustration from J. A. Ford, Figure 3 of "On the Concept of Types: The Type Concept Revisited," in American Anthropologist 56: 42-54. (C) American Anthropological Association.

ISBN 0-306-45537-4 (Hardbound)

ISBN 0-306-45538-2 (Paperback)

(O) 1997 Plenum Press, New York

A Division of Plenum Publishing Corporation

233 Spring Street, New York, N. Y. 10013

http://www.plenum.com

All rights reserved

10987654321

No part of this book may be reproduced, stored in a retrieval system, or transmitted in any form or by any means, electronic, mechanical, photocopying, microfilming, recording, or otherwise, without written permission from the Publisher

Printed in the United States of America 


\section{Preface}

Over forty years ago Gordon R. Willey (1953b:361) stated that "[t]he objectives of archeology ... are approached by the study and manipulation of three basic factors: form, space, and time." A few years later, Albert C. Spaulding (1960b:439) repeated this thought using different words: "[A]rchaeology can be defined minimally as the study of the interrelationship of form, temporal locus, and spatial locus exhibited by artifacts. In other words, archaeologists are always concerned with these interrelationships, whatever broader interests they may have, and these interrelationships are the special business of archaeology."

Many of the means Americanist archaeologists use to examine formal variation in artifacts and the distribution of that variation across space and through time were formulated early in the twentieth century. The analytical tenets, or principles, underlying the various methods and techniques were formalized and axiomatized in later years such that by the 1930s they constituted the first formal paradigm for Americanist archaeology - a paradigm commonly termed culture history. This paradigm began with a very specific goal-to document the history of the development of prehistoric cultures in the Americas. Although it fell from favor in the 1960s, many of its central tenets were carried over to newer paradigms and thus continue to be fundamental within Americanist archaeology.

With Willey's and Spaulding's conceptions as our guide, we elsewhere reprinted (Lyman et al. 1997) what we view as the benchmark papers of culture history, in which the fundamental principles of the paradigm were established. We compiled and reprinted the papers because it is our strong impression that many archaeologists today tend to overlook the central tenets of the discipline - tenets that underpin virtually everything we do. Moreover, contemporary knowledge of our discipline's past often appears to be derived from secondary sources that often impart orientations and characteristics that the original authors would not recognize. Thus, we find ourselves in strong agreement with Bohannan and Glazer (1988:xv), who note 
that ignorance of a discipline's past can result in "unnecessary originality" while detailed knowledge of it can "give one a great many good ideas, for the past never says things quite the way the present needs them said."

To place those benchmark papers in a comprehensible context, we provided a brief overview of how the elements of time, space, and form, in various guises, came to assume center stage in Americanist archaeology after the beginning of the twentieth century (Lyman et al. 1997). Our discussion was necessarily abbreviated, and while we noted how and why the culture history paradigm took the form that it did, we did not go into great detail. It is our purpose in this volume to do just that. Our essay is written from a critical viewpoint and seeks not only to document the history of the culture history paradigm but also to demonstrate why that paradigm flourished for a time and why it was ultimately set aside by a large segment of the discipline. The structure of our essay is partly chronological and partly topical. In most cases it is impossible to separate a discussion of time from discussions of space and form, and hence a mixed chronological and topical structure appeared to represent the best means of organizing the discussion in coherent fashion.

The number of Americanist archaeologists who contributed to the development of the culture history paradigm is large. There are, to be sure, some figures who were more central than others to that development, and it is, of course, the former's work to which we devote much of our attention. The story is an intriguing one, and not just because one might construe the first few decades of the twentieth century as the "good old days" of Americanist archaeology, when every newly found site or excavated trench revealed previously unknown kinds of artifacts or promised to fill a gaping hole in knowledge. Sometimes the history of Americanist archaeology during that period is so characterized either directly or indirectly (e.g., Givens 1992; Lyon 1996; Woodbury 1973). To be sure, it was an exciting time for precisely these kinds of reasons (see especially Elliott 1995), but with the benefit of hindsight, it was also an incredibly intellectually stimulating time. Some histories have tried to capture that feeling and discuss the implications thereof (e.g., Trigger 1989), whereas others have chronicled the names of the excavators, the names of the sites excavated, the dates of excavation, and some of the analytical innovations that resulted (e.g., Fitting 1973; Willey and Sabloff 1974, 1980,1993). We seek to do more than that here.

The intellectual history of the culture history paradigm is informative as to the status of the discipline today. Not only can the origins of certain innovative analytical techniques be traced, but the reasons for their innovation can be determined. Why was there a stratigraphic revolution in the 1910s? Or, was there really such a revolution? Why are there so many ways to seriate artifact collections, and where did these various techniques come 
from? What theoretical notions, if any, underlay their development? What is a component, a focus, a phase, a tradition, a horizon, and do such units have a role to play in the discipline today? If so, what kind of role? Did Folsom evolve from Clovis, did Mississippian evolve from Woodland, or were these the result of migrations of different groups of people? Why would we think that any of these scenarios might be correct or incorrect, and how might we go about choosing one over another? In short, how and why do we know what we think we know about the prehistory of the Americas in so far as that prehistory is reflected along the dimensions of time, space, and form? Producing an answer to that question is the major goal of this volume. The answer hinges on understanding how and why the culture history paradigm developed the way it did.

We thank Eliot Werner of Plenum Press for his continued interest in this project and Mary Curioli and Herman Makler of Plenum, who helped us get the manuscript in publishable shape. We also thank the American Anthropological Association for permission to use Figure 3 from James A. Ford, "On the Concept of Types: The Type Concept Revisited," American Anthropologist 56: 42-54 on the cover of the book. Dan Glover tracked down numerous references and redrafted all the figures, and Jennifer Smith Glover proofread the manuscript. Correspondence with Jon L. Gibson, William G. Haag, and especially James B. Griffin helped tremendously when it came to some of the fine details. Comments on a draft by several anonymous reviewers, and especially the very sharp eyes of E. J. O'Brien, are appreciated. 


\section{Contents}

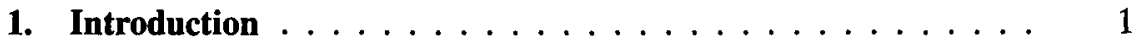

Science and Kinds of Science . . . . . . . . . . . . . 3

Essentialism and Materialism . . . . . . . . . . . 4

Units ....................... 6

Specimens and the Problem of Analogs versus Homologs . . 8

An Abstract . . . . . . . . . . . . . . . . . 11

2. Before Culture History . . . . . . . . . . . . . . 13

Classification and the Formal Dimension . . . . . . . 15

Space . . . . . . . . . . . . . . . . . 17

Time ....................... 20

Measuring Time Stratigraphically? . . . . . . . . . 23

Measuring Time with Form? . . . . . . . . . . . . 28

Summary . . . . . . . . . . . . . . . . 30

3. The Birth of Culture History $\ldots \ldots \ldots \ldots \ldots \ldots$

Franz Boas and Manuel Gamio . . . . . . . . . . . . 34

Nels C. Nelson . . . . . . . . . . . . . . . . . . . . . 37

A New Metaphysic . . . . . . . . . . . . . . 43

Alfred V. Kidder . . . . . . . . . . . . . . . . . . 46

Alfred L. Kroeber . . . . . . . . . . . . . . . . . 55

Leslie Spier . . . . . . . . . . . . . . . . . . 59

The Aftermath ................. 63

The Direct Historical Approach . . . . . . . . . 70 
4. After the Revolution . . . . . . . . . . . . . 73

Measuring Time with Strata . . . . . . . . . . . . 74

The Trouble with Superposition . . . . . . . . . 74

Index Fossils . . . . . . . . . . . . . . 76

Stratigraphy and Empirical Standards . . . . . . . . 76

Strata as Units of Time and Units of Association . . . . . . 77

George C. Valliant . . . . . . . . . . . . . . . 78

The Formal Dimension-Early Thoughts . . . . . . . 86

The Origins of Types . . . . . . . . . . . . . . . 89

Classification of Artifacts-The Search for Historical Types . 92

In the Southeast . . . . . . . . . . . . . . . . . 94

In the Southwest $\ldots \ldots \ldots \ldots \ldots \ldots \ldots$

J. O. Brew and the Death of Phylogenies . . . . . . . 101

The Formal Dimension-Post Hoc Synopses . . . . . . . . 104

Irving B. Rouse . . . . . . . . . . . . . . . . . . . . . . 104

Alex D. Krieger . . . . . . . . . . . . . . . . . 108

The Type-Variety System . . . . . . . . . . . . . 110

Some Final Efforts to Control the Formal Dimension . . . . . 114

Summary . . . . . . . . . . . . . . . 118

5. Artifact Classification and Seriation $\ldots \ldots \ldots \ldots \ldots$

James A. Ford . . . . . . . . . . . . . . . . . . . 122

Seriation Matrices . . . . . . . . . . . . . . 133

The Lower Mississippi Alluvial Valley Survey . . . . . . . . . 137

Beyond Seriation-The Debate Begins . . . . . . . . . . . 144

The Empiricist Challenge to Artifact Classification-The

Debate Continues . . . . . . . . . . . . . . . . 149

Summary . . . . . . . . . . . . . . . . . 157

6. Classification of Artifact Aggregates $\ldots \ldots \ldots \ldots \ldots$

The Midwestern Taxonomic Method . . . . . . . . . . 160

In the Southwest . . . . . . . . . . . . . . 166

Phases, Components, and Stratigraphy . . . . . . . . . 171

Formalization of the Classification of Aggregates . . . . . . 177

Horizons, Horizon Styles, and Traditions . . . . . . . 185 
The 1955 Seminars . . . . . . . . . . . . . . . . . . . . 194

Culture Contact . . . . . . . . . . . . . . . . 195

Culture Stability . . . . . . . . . . . . . . . . . . 197

Area Co-traditions and Whole-Culture Traditions . . . . . . 203

Summary . . . . . . . . . . . . . . . . . . . . 204

7. Culture History, Cultural Anthropology, and Cultural

Evolution . . . . . . . . . . . . . . . . . . . . . 207

Cultural Anthropology . . . . . . . . . . . . . . . . . . . 209

Cultural Evolution Did Not Die in 1896 . . . . . . . . . . . 219

The Fall from Favor . . . . . . . . . . . . . . . . . . . 224

8. An Ending Note . . . . . . . . . . . . . . . . . 227

References. . . . . . . . . . . . . . . . . 233

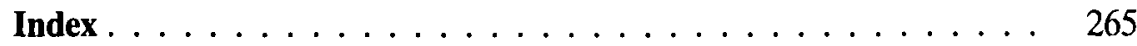




\section{Tables and Figures}

\section{Tables}

3.1. A. L. Kroeber's Pottery Types from Sites around Zuñi Pueblo, New Mexico . . . . . . . . . . . . . . . . . . . 58

6.1. Harold Gladwin's Alignment of Archaeological Units Used in the Southwest with Those of the Midwestern Taxonomic Method . . . . . . . . . . . . . . . . . . . 168

6.2. Scale Relations of Some Culture History Units . . . . . . . . 188

7.1. List of Historical Culture Processes Called Upon by Culture Historians to Help Explain the Archaeological Record . . . . . 212

\section{Figures}

2.1. Diagram of a cross-sectional excavation of a shell midden in Maine made by Frederic Loomis and D. Young in 1909 .

3.1. Map of the Valley of Mexico showing the locations of sites

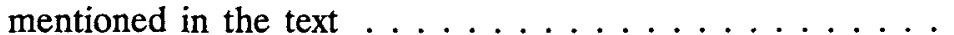

3.2. Manuel Gamio's stratigraphic profile at Atzcapotzalco in Mexico City ................... 36

3.3. Map of Arizona and New Mexico showing locations of sites mentioned in the text .............. 40

3.4. Nels Nelson's data from Pueblo San Cristóbal . . . . . . . . 42

3.5. A. V. Kidder's summary diagram of the stratigraphic relations of pottery types at Pecos Pueblo . . . . . . . . . 49

3.6. An example of M. Kidder and A. V. Kidder's (1917) percentage-stratigraphy graphics . . . . . . . . . . 52

3.7. A. V. Kidder's illustration of the evolution of a ceramic

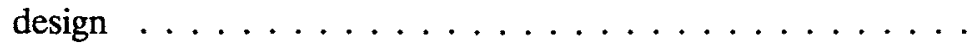


3.8. Nels Nelson's summary diagram of the time-space distribution of cultural forms in the Southwest . . . . . . . . 64

4.1. E. B. Sayles's chart of the development of manos and metates at Snaketown . . . . . . . . . . . . 87

4.2. Dimensions and attributes used by Harold Colton and Lyndon Hargrave to classify Southwestern rim sherds . . . . . 98

4.3. Harold Colton and Lyndon Hargrave's hypothetical representation of the relation between a series and its types. . . . . . . . . . . . . . . . . . .

4.4. Irving Rouse's depiction of diffusion and persistence of traits .

4.5. Alex Krieger's six-step method for constructing archaeological types . . . . . . . . . . . . . .

4.6. Two pottery clusters illustrating the Wheat-Gifford-Wasley type-variety system $\ldots \ldots \ldots \ldots \ldots \ldots$

5.1. James Ford's model of pottery-decoration complexes, pottery types, and village sites . . . . . . . . . . .

5.2. Map of the central Mississippi River valley showing the analytical quadrats employed during the Lower Mississippi Alluvial Valley Survey ... . . . . . . . . . . . . .

5.3. Model of the way in which Philip Phillips, James Ford, and James Griffin conceived of pottery types . . . . . . . .

5.4. James Ford's model of the diffusion of types across space . .

5.5. Composite profile diagram of Cut A, Rose Mound, Cross County, Arkansas, with relative percentages of three pottery types by excavation level superimposed . . . . . . . .

5.6. Variation in housing through time on James Ford's fictitious island of Gamma

6.1. The analytical relations among traits, components, and foci in the Midwestern Taxonomic Method . . . . . . . . . . . .

6.2. James Ford and Gordon Willey's alignment of archaeological phenomena along a south-to-north transect from Baton Rouge, Louisiana, to Grand Rapids, Michigan . . . . . . . . .

6.3. Irving Rouse's model of the results of comparing phases to show their relative positions in form, time, and space . . . . .

6.4. Five types of traditions recognized by participants in the 1955 Society for American Archaeology-sponsored seminar on cultural stability . . . . . . . . . . . . . . 200

6.5. The Wheat-Gifford-Wasley conception of the relations among pottery variety, type, type cluster, series, ceramic system, ceramic sequence, and ware $\ldots \ldots \ldots \ldots \ldots$ 